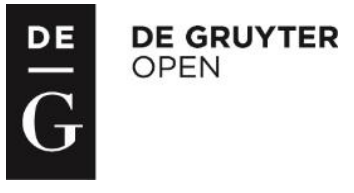

\title{
Luminița-Elena Turcu*
}

Faculty of Letters and Communication Sciences, Ștefan cel Mare University of Suceava, 13 Universităţii Street, 720229 Suceava, Romania e-mail: 1_turcu@yahoo.com

\section{"A PERSON NOT IN THE STORY": CLÉRAMBAULT’S AND M. R. JAMES'S TEXTILE/TEXTUAL FOLDS}

\begin{abstract}
Though unrelated when it comes to their scientific occupations, Clérambault and M. R. James give to the $21^{\text {st }}$-century observer the impression that they were strikingly similar in their compulsive preoccupation with draped bodies or with what Gilles Deleuze names "the Fold". The article investigates the manner in which the French psychiatrist exploited his passion in the innumerable photographs he took in Morocco and in which the English philologist exorcised his fear in fiction, especially in one of his best-known short stories, "Oh, Whistle and I'll Come to You, My Lad".
\end{abstract}

Keywords: Clérambault, M. R. James, "Oh, Whistle”, the Fold, photography, ghost story.

Gaëtan Gatian de Clérambault (1872-1934) was a French psychiatrist best known for his important contribution to the study of delusions and his name has been given to the syndrome that he first described in 1927 as "psychose passionelle", later termed erotomania, basically referring to the paranoid misapprehension in which a person believes that he or she is the focus of attention of some renowned personality. He was a psychiatrist of the Parisian police and his avid passion for NorthAfrican clothing enabled him to deliver captivating lectures on the subject at the École des BeauxArts. Clérambault's interest in the Oriental fabrics and draped coverings was born in the course of his two-year stay in Morocco where he had been sent to recover from serious injury in the First World War. There he took thousands of photographs of local people's draped bodies with an alleged ethnographic purpose. Yet, as Doy remarks, "the people in the photographs are there basically as actors, as an element in the image. They are neither subject nor object. This attitude to the body is quite unusual in ethnographic photography." (2002: 116 -7) In 1908 he published "Passion érotique des étoffes chez la femme," an article on the atypical sexual behaviour of a number of women who had stolen silk from department stores in Paris and who, under interrogation, gave him the details of "the erotic and psychological dimensions of [their] criminal acts." (Coulson, 2013: 46) It is in this article and in the sequel published a couple of years later that de Clérambault makes a gender disjunction of fetishism, favouring the male over the female one: whereas the former "represents an 'homage to the opposite sex', the perverse female passion for cloth is rooted in the very refusal of this fantasy" (Copjec, 1989: 87), in selfishness, and in solipsism.

\footnotetext{
* Luminița-Elena Turcu is Assistant Professor at Ștefan cel Mare University of Suceava, Romania, where she teaches Victorian and Gothic fiction.
} 
In the autumn of 1934, half blind and dismissed from L'École des Beaux-Arts, he shot himself in front of the mirror, with a camera focusing his reflected image. His death was soon followed by a storm of malicious gossip instigated by the discovery that the doctor kept in his house hoardings of Oriental cloth, Indian madras, and several wax mannequins (Gavin, 2009: 59-60). Most probably, the paraphernalia had been used as teaching aid, yet it was sufficient for the press to name him "a new Caligari" (Copjec, 56) and the fact that Clérambault was a police psychiatrist fed even more the public's conspiratorial fantasies of power. Clérambault's position of a police expert in psychiatry is indeed ambiguous since, as Foucault maintains, "its function is to constitute, to call up, anOther doubling, or rather, a group of further doublings. There is the constitution of a doctor who is at the same time a doctor-judge." (2003: 21-2) The interest in the eccentric specialist's name and destiny eventually faded away to be revived at the turn of the $21^{\text {st }}$ century by way of a series of highly influential literary and cultural approaches of his photographic work, starting with Gilles Deleuze's The Fold (1991). Lots of questions still haunt today's criticism: was Clérambault a "dispassionate observer or impassioned fetishist? aesthete or man of the world? his suicide, was it motivated by his failing sight, dwindling finances, or rising insanity?" (Copjec, 58)

In the same period of time but on the other side of the Channel, Montague Rhodes James (1862-1936) - "the master of the early twentieth-century ghost story" (Punter, 2004: 132) - was also known for his doubling of functions. He was provost of King's College, Cambridge, later of Eton, and an expert in theological and medieval studies, in ancient manuscripts and palaeography. His twofold status, of celebrated writer and highly esteemed scholar, allowed him to restore the Gothic genre through antiquarian accessories and bookish ambiance with the aim of "suspending the reader's disbelief" (Cox, 1987: xviii), also of looking at implausible happenings with a combination of detachedness and "a faintly self-mocking note." (Brewster, 2012: 41) His first ghost stories were collected in 1904 under the title "Ghost Stories of an Antiquary" and were followed by three more volumes published between 1911 and 1925. The word "antiquary", Jacqueline Simpson states, "already had an old-fashioned charm about it, and was appropriate for a scholar whose work revolved round medieval manuscripts, biblical Apocrypha, library catalogues, church iconography and the like.” (1997: 9) The haunted castle in traditional Gothic is changed in M. R. James's ghost stories into a university library, a church or some commonplace location, such as a seaside boarding-house or a country inn. The regular victims of the creepy disruptions that occur in such places are usually sceptical unworldly academics. "James's dons rarely respond with horror but with curiosity and a disdain for superstition, and are represented as strangely unempathetic." (Spooner and McEvoy, 2007: 151) M. R. James's ritual of reading a ghost story on each Christmas night to his friends - most of them cynical dons themselves - unveils the nature of the complicity between reader and writer that his stories takes for granted, also of the self-irony that he considered essential for the proper composition of and the adequate response to his stories. Then again, as Scott Brewster aptly remarks, "James's selfdeprecating authorial persona, and the carefully cultivated sense that the tales were merely jeux d'esprit, have led critics to overlook the subtlety and complexity of his stories." (41)

It appears that both Clérambault and M. R. James - highly esteemed specialists in their field of knowledge - had a hobby that was largely divorced from their scientific concerns and which gradually turned from minor pastime into an all-absorbing occupation. Still, while in Clérambault's case the fascination for photography was voracious and toxic, James's fondness of ghost stories never proved detrimental to his psychological integrity. Though clearly unrelated when it comes to their scientific occupations, Clérambault and M. R. James give to the $21^{\text {st }}$-century observer the impression that they were strikingly similar in their compulsive preoccupation with draped bodies or with what Gilles Deleuze names "the Fold". If there is any conspicuous area of intersection between their distinct scientific careers that is to be found in the overlapping interest of the two in Oriental clothing: James seems to have been terrified with it and Clérambault was unmistakably charmed by it. The French psychiatrist exploited his passion in the innumerable photographs he took in Morocco and then exposed and discussed in Paris while the English philologist exorcised his fear in fiction, especially in one of his best-known short stories, "Oh, Whistle and I'll Come to You, My Lad".

The story was included in the first collection of 1904 and it combines precisely the abovementioned ingredients that will make James's fiction distinguishable: a peaceful setting, imbued with some secret history, an antiquarian mystery, and a disturbing rapid sequence of events that baffle and terrify the rather insipid Professor Parkins who has come to a seashore inn to improve his skill in 
playing golf. He is introduced to the reader as he has dinner with some of his colleagues in the hospitable hall of St James's College just before his vacation. In few pages the reader finds out what his plans are and what kind of a person he is, in his own eyes as well as in the eyes of his fellow academics. Parkins is described as "young, neat, and precise in speech" (James, 109) and he takes pride in being "indeed, scrupulously polite and strictly truthful" (111). Yet, to his colleagues, the Professor of "Ontography" is "an old woman - rather hen-like, perhaps, in his little ways; totally destitute, alas! of the sense of humour, but at the same time dauntless and sincere in his convictions, and a man deserving of the greatest respect." (112) M. R. James gives the formula for such unpromising narrative openings in the introduction of "Madame Crowl's Ghost":

Let us, then, be introduced to the actors in a placid way; let us see them going about their ordinary business, undisturbed by foreboding, pleased by their surroundings; and into this calm environment let the ominous thing put out its head, unobtrusively at first, and then more insistently, until it holds the stage. (in Carroll, 1990: 247)

As for the conclusion of the story, the writer presents the concept of a "loophole"- that is, a slight chance given to the reader to pinpoint a logical clarification of the absurd and unnatural doings that he has provoked and witnessed: "It is not amiss sometimes to leave a loophole for a natural explanation, but I would say, let the loophole be so narrow as not to be quite practicable" (id., 237) In between the opening and the closing lines of the antiquarian ghost story, there is the familiar mechanics of original disbelief bent into revulsion and perplexity through some vicious obtrusiveness, curiosity or greed on the part of the protagonists as "these antiquarians are like Heisenbergian researchers: there is no way to uncover the past without disrupting it, disturbing it, even producing it. It is messing around in the archives, disturbing the records of the past that prompts the ghosts to turn up in the first place: archivists produce ghosts, we can say as a shorthand.” (Hay, 2011: 96)

Once arrived at Burnstow, Professor Parkins spends most of his time on the field of the Globe Inn, practicing golf. His regular companion is Colonel Wilson, a voluble and robust ancien militaire. One evening Parkins decides to stroll along the beach by himself and, on his fellow Professor Disney's request, to inspect the ruins of a Templars' preceptory. He is supposed to examine the site and see if the vestiges are worth some archaeological digging. It is getting dark and he walks with difficulty "on the broken ground covered with small depressions and mounds." (114) He searches around the ruins, meditating on the difference between amateurs and professionals, and soon discovers "an artificial hole" near what he believes to be "the base of a platform or altar." (ibid.) Using his pocket-knife, he unearths a small tubular object made of metal which later proves to be an ancient whistle. He puts it in his pocket and hurries back to the inn, but he has the unsettling feeling that he is being followed by someone "in the shape of a rather indistinct personage, who seemed to be making great efforts to catch up with him, but made little, if any, progress..." (115) Back in his room, he examines the mysterious object and can distinguish some curious inscriptions on it:

Why, surely there were marks on it, and not merely marks, but letters! A very little rubbing rendered the deeply-cut inscription quite legible, but the professor had to confess, after some earnest thought, that the meaning of it was as obscure to him as the writing on the wall to Belshazzar. There were legends both on the front and on the back of the whistle. The one read thus:

$\begin{array}{lll}\text { FUR } & \text { FLA } & \\ & \text { FLE } & \text { BIS }\end{array}$

The Other: Quis est iste que venit. (118)

He finds the latter inscription easier to decipher as "Who is this who is coming?" and decides, jokingly, that "the best way to find out is to whistle for him." (119) As he stands in the window of his room, he blows the whistle twice and a terrible gust of wind opens it and blows out the bedside candle. He struggles to shut the window "as if he were pushing back a sturdy burglar" (119) and spends the rest of the night listening to the furious wind outside. In the morning, the maid remarks that both beds in his room have been slept in. An entire chain of confusing events follows, all of them suggesting that a strange creature actually inhabits the spare bed in Parkins's room. The climax resides in the 
protagonist's nauseating discovery that the (un)invited room-mate has fashioned a body for himself out of bed sheets and that he now moves around his room in a fluttering draped frame that seems to conceal no body. His two male companions - Colonel Wilson and his colleague Rogers, who has just arrived at the inn - restore the order expulsing the bizarre creature simply by throwing the whistle into the sea and burning the polluted bed sheets:

Early on the next day Rogers arrived, more welcome than he would have been a day before, and the three of them held a very long consultation in the professor's room. At the end of it the colonel left the hotel door carrying a small object between his finger and thumb, which he cast as far into the sea as a very brawny arm could send it. Later on the smoke of a burning ascended from the back premises of the Globe. (133)

The story has incited all kinds of critical approaches, some of them discerning elements of "homosexual panic" in this plot of minor transgressions that lead to excessively ghastly consequences. Indeed, the unattached Parkins is an oddity in a world that approves of heterosexual couples only and he is warned against this type of prejudice before he books a room at the Globe when "they tell [him] that the only room of any size [he] can have is really a double-bedded one." (110) The purpose of his stay is again dubious as golf can hardly be described as a manly game. Golf players benefit from a combination of privacy and liberty that can be but questionable to a suspicious mind. Parkins and Colonel Wilson "play well enough during the afternoon or, at least, well enough to make them forget everything else." (126) Away from any observer, they enjoy each other's company for long hours yet the reader is given a shorthand of their activities on the field. The record of "what he had called improving his game, in company with this Colonel Wilson" (113) is evasive and intermittent and "the golfing reader" (124) is expected to account for all kinds of interruptions and hiatuses and "to imagine appropriate digressions at the proper intervals." (Id.) Moreover, the title of the story, Darryl Jones remarks among other critics, "is taken from a Burns ballad about the seduction of a maid" (2011, xxiv), thus illustrative of its erotic charge. Yet, the one "who is coming" when whistled upon is here a man. To this we may add the giggle of the maids when one of them remarks the untidy spare bed with "all the things ... crumpled and throwed about all ways... quite as if anyone 'and't passed but a very poor night." (123) Some other critics read the ethereal draped body as the transcript of the common fascination exotic drapery held for Western eyes.

Clérambault's photographs, which were taken "at the very height of the 'golden age' of French colonialism" (Copjec, 59), have been described as illustrative of his fixated and lustful attraction towards Islamic arranging of clothes. Gilles Deleuze considers that the French scholar's delirious fascination with folded cloth is rooted in the discovery of "the tiny hallucinatory perceptions of ether addicts in the folds of clothing" and goes beyond "a simple personal perversion", evoking a certain " "texture' of the Baroque." (q. in Gavin, 56-8) Indeed, in one of the few surviving texts written by Clérambault on the Fold, the scientific discourse subverts the boundaries of exactitude and the surfeit of fetishist traits gives it the quality of a frenzy of jouissance:

\begin{abstract}
We have drawn the attention of artists to the diverse forms of the fold: the fold as garland, puckered, like a nest, a groove, a fan, agitated; folds falling and rising; active and passive folds; folds that spurt, folds that are constricted; folds of traction and suppressed folds ... We have pointed out the schematic flexion of thick cloth, the transparency and limpid tones of thin cloth, the back-lighting seen in interiors or outdoors, the effects of wind, the association of spiral forms to the large movements of the human body, and finally the gestures, unconsciously regulated, of the construction of drapery, as inexhaustible themes of art. (q. in Doy, 2002: 120)
\end{abstract}

Clérambault's ambition was to prove that the manner of fastening cloth specific to the North African populations - in terms of knots, ligatures and fixing points - was related to the way in which the ancient Greeks and Romans draped their bodies. He compared antique costumes as reflected in classical European sculpture and bas-reliefs to be admired in the Louvre with the Islamic draping as seen in his own photos. The pertinent ethnographic project of describing national identity through the traditional practices of dressing was undoubtedly part of the colonialist project of France with its insistence on the dual relatedness of France with ancient Greek and Roman civilization, on one hand, and of ancient Greek and Roman culture with that of Islam, on the other hand. 
The sartorial technique is however irrelevant for nowadays observers who are stunned at the shrouded bodies' ghost-like appearance which brings to their mind images of Guantanamo convicts or of some other prisoners' hesitant march in an unspecified airbase, with their heads covered and the colourless clothes fluttering about their indiscernible bodies. Without seeing their faces or bodies, we know today that they are certainly Islamic, also presumed terrorists, that is, "enemies of the West". Clérambault's age was one in which the body of the Oriental Other was still under construction and the fact is obvious in the manner in which the body of the Other, largely unknown to the West at the time, links the colluding pleasure of domination with desire. That the body might be at stake and not the clothing as such is revealed in a letter Clérambault sends to the State Undersecretary for Fine Arts, in which he campaigns for his course in drapery and describes himself as more apt than others to deliver it since, as a doctor, he is more familiarized with the human body, "the life of drapery" being also "a kind of biology." (Doy, 119) In Images of Women (1988), Sarah Graham-Brown detects a "reverse striptease" in Clérambault's photographic work with the body fully cloaked and the viewer anticipating the clandestine pleasure of exposure. On the contrary, Joan Copjec demonstrates in her ground-breaking article of 1989, "The Sartorial Superego," that "Clérambault did not always position himself as the colonialist subject confronted with an obstacle to his vision or knowledge, that is, with an objectified image of his own loss. He instead often placed himself as the gaze of the Moroccan Other." (91-2) The Colonial Other enjoys a "surplus pleasure, the useless jouissance" (Copjec, 87) of the ample fabric and Copjec sees in this presence "the objectified, sartorial form of the Freudian superego." (ibid.)

I will slightly depart from these opinions and employ only Joan Copjec's synthetic formulas for fantasy and fetish to distinguish between the meanings of draped bodies in Clérambault's and M. R. James's work:

\begin{abstract}
$\mathrm{S}<>$ a, i.e., the split subject (S) is in some form of relation $(<>)$ to an object (a), can be simply inverted to obtain the formula for perversion: a $<>\mathrm{S}$. But what does this mean? In the fantasy, the subject establishes a relation to the object-cause of its desire (a), to an object that "presentifies" the subject's loss. Although this loss is presented in an externalized form and therefore represents a misrecognition of the subject's internal impossibility, the subject does, nevertheless, constitute itself in relation to this objective lack. In the colonialist fantasy of cloth, for example, the utilitarian subject maintains a desire to see what lies behind the veil or to end the excess pleasure concealed by it. The pervert, however, refuses all recognition of his own lack, even in external form. (89)
\end{abstract}

My thesis is that Clérambault's pictures are, like all fetish objects of the kind, simply residues of the colonial fantasy of unveiling the body of the colonial subaltern, of knowing it. This fantasy left visible traces in his photography especially if we take into account the fact that he never asserted that what he was doing was art. Instead, he chose a scientific justification for his pursuit, for the need to document specific traditions that were on the point of extinction. That the indicated disappearance was the direct effect of brutal colonialism was never made clear in his plea for such a noble endeavour as his. One can sense instead the exasperation of the fetishist when the psychiatrist utters his fear that draped clothing might soon disappear since "already Arab clothing is being sewn, rather than draped." (Doy, 117)

Yet, his "noble mission" was doomed to fail. First of all, the French scholar's pictures were useless from the perspective of the colonial power and this explains why his course on drapery was cancelled despite its growing popularity. According to Copjec, Clérambault wrote a passionate letter to the authorities in which he spoke about his efforts in "an exact rendering of the Fold" (95), involuntarily capitalizing the word that designates his fetish. Secondly, there appears to be no ethnographic interest in the body whatsoever as in Clérambault's photos the human frame is clotted under a heap of material that conceals everything not with purpose of inciting a pleasurable unveiling but because the body is uninteresting. The above-mentioned Lacanian formula in Copjec's study clarifies the position of the fetish as "the site of a merging or confusion of subject and object" (Dant, 1996: 504), with the object steadily gaining supremacy over the subject. There is no libidinal concern in these bodies comparable to the illustrations that circulated in the age, with graspable innuendos at voluptuous bodies hidden behind the veils. Some of Clérambault's pictures show women draped in white fabric, but many more show men. Women are usually presented in groups and even though their 
sex is difficult to distinguish, they are presented in postures that are customarily associated with femininity from a non-Oriental standpoint (leaning back on some hard surfaces, holding a wrapped doll-like infant near the unseen breast) or from a presumed Oriental viewpoint (standing in a silent timorous congregation or clustered on the ground with their heads bent and wholly shielded by the greyish cloth, looking like sand dunes - motionless, perfectly curved, and inanimate). In contrast, men are presented in more lively positions: with their arms spread or gathered on their heads. Some other times they are shown moving around the villages or revealing to the photographer part of the elaborate art of wrapping themselves in cloth. These are the eeriest of them all. Men's arms are spread above their heads and stripes of pale cloth are falling down, clinging from their raised hands. Their faces are covered so as to leave only a narrow black opening, a perfectly dark visor, where the eyes should be. The impact on contemporary viewers might have been formidable. It still is.

Nevertheless, the most expressive of Clérambault's images are the bizarre representations of human beings - no one can tell whether they are male or female anymore - who are standing, cloaked in drapery from head to toes. It is here that the meaning of the Fold - capitalized, as in Clérambault's letter or in Deleuze's essay - is discernible. The human frame is rendered superfluous as the fold seems to have gained a life of its own. Somewhere, just below the line of the shoulders, there is crinkle of the fabric indicating that an invisible hand has clasped it from within to keep it together. It is the only sign that the Fold might be related to a human presence, yet the overall impression one gets is that the Fold has a breach there that has been briskly sealed and screened by further drapes of cloth. This is the Gothic vision of the fetishist: the object that is useless for the subject's gratification of desire, since it is pleasurable to the Other and not to the fetishist, appears to be able to replicate the type of desire that the fetishist wants to erase and supress. As Žižek puts it, "if the signifier is the form of 'being active through anOther', the object is the form of 'being passive through anOther' - that is to say, the object is primordially that which suffers, endures it, for me, in my place: in short, that which enjoys for me. So what is unbearable in my encounter with the object is that in it, I see myself in the guise of a suffering object, what reduces me to a fascinated passive observer is the scene of myself passively enduring it." (2008: 151)

Needless to say that objet petit $a$ is one and the same for both Clérambault and M. R. James. One could never imagine a more appropriate illustration for the creature in M. R. James's story than the horrendously captivating draped bodies in Clérambault's images. Still, there is a difference between the fetish (Clérambault's) and the phobic object (M. R. James) and it lies not in the fascination the object exerts on the onlooker. What differs is the relationship between subject and object, which definitely stands for castration. In the case of the fetish, "the disavowal of the castration succeeds; while in the case of the phobic object, the disavowal fails, and the object directly announces the dimension of castration." (Žižek, 133) Oversimplifying a complex matter, in phobia the fear of castration is articulated, whereas in fetishism (symbolic) castration is rehearsed and desired. In tone with Žižek's explanation, gaze itself functions as the fetish-object in the case of Clérambault: the Fold invites a transfixed stare at the multifarious drapes that conceal the absence that cannot be acknowledged. In the case of M. R. James, the gaze is not frozen; instead, it is what David Punter names "skewed vision" and Slavoj Žižek "looking awry." Looking awry does not mean losing focus or clarity. Quite the reverse, it means finding the right perspective to look at veiled things, at objects that are meant to stay veiled so as not to reveal the lack. That is why in Parkins's vision of the Other he is unable to keep his eyes closed for long and all he can see in his mind's eye is "a little flicker of something light-coloured moving to and fro with great swiftness and irregularity." (121) The fantasy image eventually materialises as the embodiment of the objet petit $a$, which can be perceptible but with the tail of the eye, "la coda dell "occhio" (Sage, 2003, 175), or, using a Gothic cliché, "through a glass darkly." In addition to his fecund imagination, the sound of the whistle can also produce images in the hero's mind. "These epiphenomena, arising on the retina or in the ear, occur momentarily. In the horror tradition, they are usually described in a rhetorical sequence that always ends up reasserting a sceptical or disbelieving, cynically materialist, viewpoint, denying them as illusions or, rather, delusions of the individual subject, momentary derangements of the perceptual apparatus." (Sage, 176) Misperception is usually banished in classical Gothic fiction and given as a plausible explanation of abhorrence and terror because, as Jack Morgan says, "clear, stable seeing is our primary charm against evil and horror." $(2002,201)$ 
The obstinate fixation or petrification of the object of desire infers an abundance of fetishistic specifics that are reiterated in Clérambault's recurring fantasy, which takes the form of countless snapshots of similar or slightly different body postures and attire outlines. In the case of M. R. James, the metonymic displacement of desire is rather deprived of minutiae, though similarly poignant and disproportionate in the effect it has on the viewer. The British writer confessed that he was susceptible to "particular aspects of the horrific: spiders, thinness, hairiness, hooded figures and linen drapery..." (Simpson, 10) In his childhood, he had been terrified by a cardboard Ghost of a Punch and Judy toy set, "a tall figure habited in white" (ibid) with no Other detailed features. Vagueness is a familiar mark of his horror fiction while draped bodies, with their connotations of unnerving ambiguity and menace, persist in a constant nightmare of which he speaks in a story that was published posthumously, "A Vignette". It is the story of a gate with a square hole in it, which the curious narrator decides to peep through. What he can see there is strikingly similar with what Parkins finds in his bed in "Oh, Whistle":

Through that hole a face was looking my way. It was not monstrous, not pale, fleshless, spectral. Malevolent I thought and think it was; at any rate the eyes were large and open and fixed. It was pink and, I thought, hot, and just above the eyes the border of a white linen drapery hung down from the brows... (1987: 297-8)

Scared to death, the hero runs away and, when he finds himself at safe distance, he looks back to grasp only "a draped form shambling away among the trees..." (ibid) In "Oh, Whistle" there is a similar negative correlation between motion and gaze. As Žižek defines the phenomenological status of this connection, "movement equals blindness" (108) because, he goes on, "in order for us to perceive the object clearly, it must be frozen, immobilized - immobility makes a thing visible." (109) The intruder in Parkins's room is but a sum of sensations while tossing and rustling himself in the spare bed or moving around the moonlit bedroom. The horrified Professor, "with all his eyes open" (131), cannot see the invader who becomes visible only when motionless:

The personage in the empty bed, with a sudden smooth motion, slipped from the bed and took up a position, with outspread arms, between the two beds, and in front of the door. Parkins watched it in a horrid perplexity. (131-2)

The "flickering image that never finally arrives in complete form but nonetheless lodges itself in the eye" (Brewster, 48), which is specific to M. R. James's politics of terror, resembles Clérambault's "vues cinématographiées" (Doy, 117), as he called the sequence of snapshots exemplifying the process of folding the cloth. Quite often, Parkins mentions the whistle's "power of forming pictures in the brain" (119) and one such picture, he says, is "continuous. When he opened his eyes, of course, it went; but when he shut them once more it framed itself afresh, and acted itself out again, neither quicker nor slower than before." (121) To use cinematographic terminology, what happens in Parkins' room may be compared to a jammed reel during a movie projection, when the moving picture suddenly turns into a freeze frame and then into a scorching one. It is the ultimate horror of the subject's confrontation with the phobic object, with loss:

But it is not so evident what more the creature that came in answer to the whistle could have done than frighten. There seemed to be absolutely nothing material about it save the bedclothes of which it had made itself a body. The colonel, who remembered a not very dissimilar occurrence in India, was of opinion that if Parkins had closed with it it could really have done very little, and that its one power was that of frightening. (134)

What the intruder can do is terrify because he is "effectively a 'Non-Man', the desubjectivised horror of the pure drive." (Žižek, 112) The horror is born out of the anticipation of this "No-Man", similar to Clérambault's No-Body, becoming tangible. H. P. Lovecraft also associated M. R. James's "disturbing realism with the fact that his typical ghost is 'usually touched before it is seen'." (Cooper, 2010: 156) The imperative Noli me tangere! from classical Gothic fiction no longer works and in spite of the protagonist's revulsion ("he could not have borne - he didn't know why - to touch it; and as for 
its touching him, he would sooner dash himself through the window than have that happen") the fatal contact occurs in the form of something that can easily be taken for a kiss:

\begin{abstract}
With formidable quickness it moved into the middle of the room, and, as it groped and waved, one comer of its draperies swept across Parkins's face. He could not though he knew how perilous a sound was - he could not keep back a cry of disgust, and this gave the searcher an instant clue. It leapt towards him upon the instant, and the next moment he was halfway through the window backwards, uttering cry upon cry at the utmost pitch of his voice, and the linen face was thrust close into his own. (132-3)
\end{abstract}

Pressed upon his, Parkins can feel the Thing's or the Fold's "horrible, an intensely horrible, face of crumpled linen." (132) The text collapses as well as the protagonist. Both are incapable of dealing with horror, with the undecipherable "FLA-FUR-FLE-BIS", that is, with the chain of signifiers that move around the unnamed desire and around the loophole "left open by jouissance, and then closed by the symbolic system." (Rabate, 2001: 35) The threat to language is posed not only by the veiled body but also by the veil itself because, as Meyda Jeğenoğlu asserts, "there is always more to the veil than the veil." (2003: 545)

The textual Fold of M. R. James enfolds secrecy, too. First of all, it was the secret of homosexuality that could awaken in his contemporaries what Copjec names (talking about Clérambault) "the old fantasy of the public figure with a very private perversion." (56) Secondly, a certain amount of the gusto for writing "low" literature had to be curbed so as to keep immune his other persona, that of a respectable scientist. Secrecy explains in part why M. R. James's narrative is "divorced from the social project of cognitive mapping entirely; what counts as narrative pleasure in these stories is $[\ldots]$ not engagement with the project of realism, but distraction from it." (Hay, 99) The textual Fold is thus both a spectacle of disclosure and a game of concealment with rising and falling narrative drapes that cover and uncover successively part of the plot, part of the cast, and part of the readership. From the very first lines the story activates a system of exclusion and inclusion with the depiction of a character as an outsider to the story:

'I suppose you will be getting away pretty soon, now full term is over, professor,' said a person not in the story to the Professor of Ontography... (109)

The "person not in the story" is nevertheless in the story. It is true that it is only within a coil of the textual Fold. From now on its access to the rest of the story is obliterated whereas other characters are likewise allowed or disallowed to engage in the events, to witness or to comprehend them. There are various partitions of the textual fold that work successive attachments and segregations of both characters and readers, the text folding and unfolding itself in an undulated topology that constantly leaves someone outside. For instance, one of Parkins's colleagues, the one who urges him to visit the ruins of the Templars' preceptory, is allotted an undersized narrative space in the beginning of the story and treated accordingly as a narrative subaltern:

It was, as you might suppose, a person of antiquarian pursuits who said this, but, since he merely appears in this prologue, there is no need to give his entitlements. (109)

Clive Bloom considers that M. R. James's "tales are told knowing the reader already knows the rules of the game. The denouements, when they arrive, lift a veil onto nothing at all and are effective acts of psychic disturbance because they speak to open and acknowledged desire" (1993: 69) The readers know the rules as the textual Fold prescribes and inscribes certain types of readers, yet they are also partitioned by the multiple layers of the undulating Fold. Some readers are well-read and they do not need additional explanations as they are indeed familiarized with Gothic fiction and perhaps also with Latin, Greek, history and are fond of intellectual games. That is why one inscription on the whistle is explained while the other is not: those who know some Latin also know that the translation is only one possible version and those who don't know Latin will immediately swallow the given explanation. As for the enigmatic inscription, that is only for the cognoscenti or perhaps for a small circle of M. R. James's friends. There is also the rather disconcerting category of the "golfing readers", who are supposed to know something that the non-golfing readers don't. Describing the 
game played by Parkins and Colonel Wilson, the narrator winks at "the golfing reader [who] will have to imagine appropriate digressions at the proper intervals..." (124) Some other times the narrator decides to leave all readers outside and envelop only himself and the protagonist within a textual fold:

I can figure to myself something of the professor's bewilderment and horror, for I have in a dream thirty years back seen the same thing happen; but the reader will hardly, perhaps, imagine how dreadful it was to him to see a figure suddenly sit up in what he had known was an empty bed. (131)

Every now and then the protagonist is left aside by other characters, isolated by their caustic mockery. Such is the case with Rogers who ridicules Parkins only to be immediately scorned himself for having quoted inaccurately from Dickens. The narrator exposes Rogers' ignorance in a footnote thus establishing one of the rare asides with the (golfing and non-golfing) readers when all dramatis personae are consigned to absence. Voided of the traditional Gothic techniques of entrapment, the text turns into a devious machinery in which characters and readers lose their textual grip and are flung from one position unto another as they are singled, coupled, grouped and forced to slide from one coil of the Fold into another in a relentless pirouette.

The veil conceals in both Clérambault's photographic work and M. R. James's ghost story what should never be revealed: that the body as text is being destructured in the process of its reproduction as a text readable by the West. What the drapes conceal are but other drapes that camouflage one another ceaselessly, indicating, as Joan Copjec states, "not that we can ultimately penetrate what has previously seemed the unfathomable secret of the subject, but that there is nothing to fathom." (58) The horrific quality of Clérambault's pictures resides in the suspicion that there could be no body (nobody) under the Fold and that it is only the Fold that matters. The textile secrecy of the French psychiatrist has a Gothic tinge because it is, in fact, "the guarantee of the identity of the subject, a private place where 'I' am alone, regardless of the way the world tries to construct or destroy "me'. I have a secret, therefore I am." (Berthin, 2010: 68) That is why Clérambault was alarmed by the probability of the Fold being sewn: the hand within that clasps the Fold is still in control of the secret and of the individual's privacy. Once sewn, the Fold will be regulated by the outside hand only. The Fold is impermanent; it is in-and-out, displaying and concealing simultaneously. The stitch is absolute; it is out-and-out, obstructing the unfolding of the Fold. The Fold is a continuous undulation including and excluding faces, bodies, voices successively because, as Deleuze maintains, "the ideal fold is a Zweifalt, a fold which differentiates and self-differentiates." (1991: 236) The duplicity of both the textile and textual Fold calls into question the limits of traditional representation - visual and narrative - which curtains off the unnamed only to be straightaway haunted by it in another coil of the texture that keeps on moving up and down, in and out, incessantly.

\section{Works Cited}

Berthin, C. 2010. Gothic Hauntings. Melancholy Crypts and Textual Ghosts, New York: Palgrave Macmillan.

Bloom, C. 1993. "M. R. James and His Fiction”, in Clive Bloom (ed.), Creepers: British Horror and Fantasy in the Twentieth Century, London: Pluto.

Brewster, S. 2012. "Casting an Eye: M. R. James at the Edge of the Frame", in Gothic Studies Volume 14 , issue 2, pp. 40-54.

Carroll, N. 1990. The Philosophy of Horror, New York: Routledge.

Coulson, V. 2013. "'Stealing Silk Is My Delight': Gaëtan Gatian de Clérambault and the Sexual Politics of Poststructuralist Feminism", in New Formations, No. 79, January, pp. 26-42.

Cooper, L. A. 2010. Gothic Realities. The Impact of Horror Fiction on Modern Culture, Jefferson, North Carolina and London: McFarland \& Company, Inc. Publishers.

Copjec, J. 1989. "The Sartorial Superego, MIT Press, October, Vol. 50 (Autumn), pp. 56-95.

Cox, M. 1987. "Introduction" to M. R. James, "Casting the Runes" and Other Ghost Stories, in Cox, M. (ed) Oxford, UK: Oxford University Press. 
Dant, T. 1996. "Fetishism and the Social Value of Objects", in The Editorial Board of the Sociological Review, pp. 495-516.

Deleuze, G. 1991. "The Fold: Leibniz and the Baroque", translated by Jonathan Strauss, Yale French Studies, No. 80, Baroque Topographies: Literature/History/Philosophy, pp. 227-47.

Doy, G., 2002, Drapery: Classicism and Barbarism in Visual Culture, London: I. B. Tauris \& Co. Ltd. Foucault, M. 2003. Abnormal. Lectures at the College de France. 1974-1975, in Marchetti V. and Salomoni, A. (eds.), translated by Graham Burchell, London and New York: Verso.

Gavin, A. 2009, "The Matter with de Clérambault: On the Baroque Obscene", in Textile, Volume 7, Issue 1. pp. 56-67.

Graham-Brown, S, 1988. Images of Women. The Portrayal of Women in Photography of the Middle East 1860-1950, London: Quartet Books.

Hay, S. 2011. A History of the Modern British Ghost Story, New York and London: Palgrave Macmillan.

James, M. R. 1987. "Casting the Runes" and Other Ghost Stories, in Cox, M. (ed), Oxford: Oxford University Press.

Jeğenoğlu, M. 2003. "Veiled Fantasies: Cultural and Sexual Difference in the Discourse of Orientalism", in Lewis R. and Mills S. (eds.), Feminist Postcolonial Theory: A Reader, New York: Routledge.

Jones, D. 2011. "Introduction" to M. R. James Collected Ghost Stories, Oxford UK: Oxford University Press.

Lewis, R. and Mills S. (eds.). 2003. Feminist Postcolonial Theory: A Reader, New York: Routledge.

Morgan, J. 2002. The Biology of Horror: Gothic Literature and Film, Carbondale and Edwardsville, Carbondale and Edwardsville: Southern Illinois University Press.

Punter, D. and Glennis B. 2001. The Gothic, Blackwell Guides to Literature, Malden, MA: WileyBlackwell.

Rabaté, J-M. 2001. Transitions. Jacques Lacan. Psychoanalysis and the Subject of Literature, Houndmills, Basingstoke, Hampshire: Palgrave.

Sage, V. 2003. "The Ghastly and the Ghostly: the Gothic Farce of Farrell's 'Empire Trilogy", in Smith A. and Hughes W. (eds.), Empire and the Gothic: The Politics of Genre, Houndmills, Basingstoke, Hampshire: Palgrave Macmillan, pp. 172-192.

Simpson, J. 1997. "The Rules of Folklore in the Ghost Stories of M.R. James", in Folklore 108, pp. 918.

Smith, A. and Hughes W. (eds.). 2003. Empire and the Gothic: The Politics of Genre, Houndmills, Basingstoke, Hampshire: Palgrave Macmillan.

Smith, A. 2007. "Hauntings" in Spooner, C. and McEvoy, E. (eds.), Routledge Companion to Gothic, New York: Routledge.

Spooner, C. and McEvoy, E. 2007. Routledge Companion to Gothic, New York: Routledge.

Žižek, S. 2008. The Plague of Fantasies, London and New York: Verso. 